\title{
Traces of "Weaving" in Hittite: A Brief Overview
}

\author{
By Marianna Pozza*
}

\begin{abstract}
The aim of the present paper is to analyze a selection of Hittite outcomes of Indo-European roots that are semantically connected with the idea of "weaving" and to compare them with other words drawn from other ancient Indo-European languages. These roots form several archaic derivatives in the Indo-European daughter dialects, and they also help us deepen our knowledge of the material culture of the Proto-Indo-Europeans. It is worthwhile, therefore, to study this small group of Hittite words, from both structural and semantic perspectives, and to provide an overview of the main etymological interpretations presented in the past by authoritative scholars.
\end{abstract}

Keywords: Etymology, Hittite, Indo-European Roots, Phonology.

\section{Introduction}

Hittite is the oldest Indo-European language attested to date, it was spoken in north-central Turkey in the $2^{\text {nd }}$ millennium BC. The royal capital city of the Hittite empire was Hुattuša (Turkish Boğazköy, now called Boğazkale), some $150 \mathrm{~km}$ east of Ankara, where most of the cuneiform tablets and table fragments have been recovered. Among the genres constituting the corpus there are edicts, treaties, letters, cult inventories, oracle practises, hymns, prayers, laws and administrative texts ${ }^{1}$.

The language was deciphered in 1915 by the Czech Assyriologist Bedřich Hrozný (1915), the scholar to whom we owe the epochal placement of Hittite within Indo-Europe. The cuneiform writing system (wedge-shaped) was a syllabic script - as was Myceaean, for example -, where each cuneiform sign represented a syllable (vowel, vowel + consonant, consonant + vowel, consonant + vowel + consonant). The Hittite cuneiform script - which is a complex one, mixing logographic and phonetic spellings - derives from the Akkadian one, which, in turn, with some changes and adaptations, adopts the cuneiform writing system of Sumerian. Hittite texts were written by experienced scribes on soft clay tablets impressed by a stylus, tablets which were subsequently hardened by drying in the sun or in an oven.

Since a large number of Hittite texts deal with magical-religious and technical subjects, it is often very hard to understand the exact meaning of the lexemes mentioned therein: the available material allows us only to grasp the global semantic field, and sometimes we can get only a general and approximate idea of the meaning of some words. The Hittite lexicon contains both Indo-European and

\footnotetext{
* Assistant Professor, Sapienza University of Rome, Italy.

${ }^{1}$ See Laroche's fundamental work (Laroche 1971) for a classification of all Hittite texts into genres (http://www.hethport.uni-wuerzburg.de/CTH/) and Hoffner and Melchert (2008) and van den Hout (2011) for their exhaustive reference grammars.
} 
non-Indo-European elements (quantitatively significant), due to contact with the subdued or neighbouring populations.

Hittite official texts contain lists of words denoting precious textiles and garments, which are of fundamental importance for a study on textile terminology within the Anatolian area. We owe the first interpretations of Hittite lexemes connected with different types of garments or clothing to Albrecht Goetze (1947, 1955 and 1956).

In subsequent year ${ }^{2}$ other scholars have analyzed Hittite textile terminology thanks to the help and progress made by archaeological discoveries (see in particular Frangipane et al. 2009 and Laurito 2013 for the situation during the Late Bronze Age), even if the archaeological evidence remains extremely limited: a few spindle whorls, loom-weights and spools have been recovered from the Late Bronze Age levels at Arslantepe, in Anatolia.

Among the recent studies that have contributed to improving our knowledge of Hittite textile terminology are those by Klengel (2008) and Vigo (2010 and primarily Vigo, forthcoming). As Baccelli et al. (2014: 110 stresses, "we have no Hittite texts that allow a clear reconstruction of the whole textile manufacturing process. The Hittite documentation offers us sporadic evidences to textile tools and techniques".

One of the main difficulties in analyzing and intepreting Hittite textile terms, in fact, is represented by the fact that these lexemes "appear in lists and inventories without pertinent data about the nature of the textile. The aim of such lists is not to qualify the textile" (Michel and Nosch 2010: xiv).

Moreover, unfortunately, the written documents do not allow us to understand with certainty if we are dealing with textile or clothing, and for this reason, in the majority of cases, the translations for such forms are of a generic type such as "cloth", "garment", "textile", etc.

\section{"Weaving" as "Linking Together": Continuous Semantic Spaces}

Within Hittite textual documentation, the most common determiner ${ }^{3}$ indicating "garment, cloth" is TÚG, which is found near words denoting dresses, garments, etc. (e.g. " ${ }^{\text {TÚG }}$ palaȟ̌ $a-$ "cloth", cf. Gr. $\pi \dot{\varepsilon} \pi \lambda o s$, or ${ }^{\text {TÚG } k u r e s ̌ s ̌ a r ~ " c u t ~ o f ~}$ cloth", etc.). The Hittite word underlying this sumerographic classifier could be, according to Goetze (1955), (TÚG) wašpa- "clothing", deverbal formation from wešš-, waššiya- "to clothe, wear, to be dressed", from IE *wes- "to clothe" (IEW: 1172-3, LIV: 192). The IE outcomes of the root *wes- are mostly nominal formations (Lat. vestis, Goth. wasti, Hitt. wašpa-, Skr. vásana- "vest, dress, garment" etc.), whereas the verbal outcomes are rarer and - as outlined by Gusmani (1968: 48) - characterized by a non-uniform structure. Greek, Hittite and

\footnotetext{
${ }^{2}$ See the excursus presented in Baccelli et al. (2014: 97).

3 For example, a semantic classifier which was not pronounced but which helped to disambiguate the interpretation of a noun.
} 
Indo-Aryan concordances show a common isoglosse (cf. Skt. váste "to be

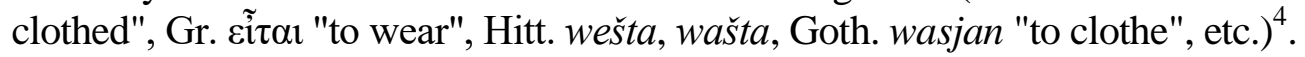

As Watkins (1969) argued, the Hittite word can be compared with Lat. vespillo "undertaker for the poorest classes, dresser (of dead bodies)", attested in Latin from the empire only, hence with the notion of providing the dead with the appropriate clothing for their burial. The scholar observes that the comparison between these two lexemes helps us to reconsruct a fragment of non-material culture for Common Indo-European Society. Metaphorical connections between the notion of "to cover" and the consequent notion of "to clothe, dress" and the like can be observed in many Hittite words, such as for example ${ }^{\mathrm{TU} G}$ kaluppa- (c.) "petticoat", if we trace it back (see Čop 1963) to IE * kel- "to hide, conceal" (IEW:

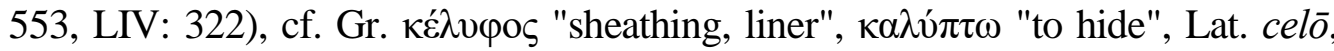
OHG helan id., Goth. huljan "to wrap, cover", etc.

Furthermore, words such as karza, karzan- "spool, bobbin (or similar)", which probably denote a weaver's tool, show the widespread relationship between the semantics of "to spin, to move quickly" and that of "to weave": cf. Skr. kart- "to spin" and perhaps krtsná- "whole, entire".

The use of the image of spinning, sewing or weaving to describe the process of linking words together seems to represent - as observed, among others, by Bachvarova (2016) - a common Indo-European metaphor. Consider, for example, the Hittite verb išhai-, išhiya- "to bind, to wrap; to obligate with, to impose upon", from which the noun išhamai- "song, melody" (literally "bound speech") derives,

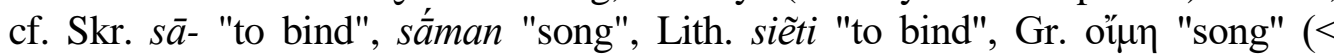

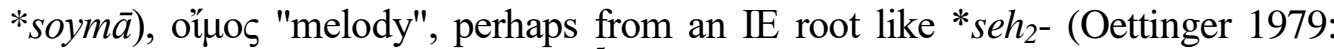
461) or *sh shy $_{2}$ "to bind" (LIV: 544)

As shown by Lazzeroni (1967: 55), in fact, the linguistic isoglosse that characterizes Greek and Hittite would shed light on the close cultural contact between the two populations that would have developed a joint concept of poetry as a link between the various parts that constitute a melody, song.

In a similar way, then, if we observe Hitt. ${ }^{\left(\text {SíG }^{\prime}\right.}$ šüil- "thread" < $*_{s y e w h}$ - $^{-}$"to bind, to sew" (IEW: 915-6, LIV: 545) ${ }^{6}$ and we compare it with cognate forms such

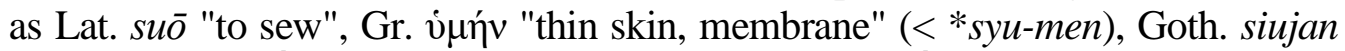
"to sew", Ved. sívyati "to sew", and the suffixed form sútra- "thread, line, cord" "on which the words are strung like beads" (Bachvarova 2016: 37) -, we notice,

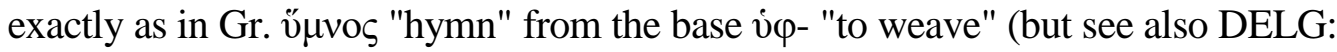
1156 for the problems connected with this etymology), the metaphorical process through which raw material can become fine poetry thanks to the act of "linking together" (see also HEG A-K: 379-380).

\footnotetext{
${ }^{4}$ See Dardano (2010) for the metaphorical use of the notion of dressing in reference to atmospheric phenomena (particularly to nightfall), and for the demonstration that this can be considered a fully Indo-European inheritance.

${ }^{5}$ Skr. $s \bar{a}$-, siyáti- "to bind" derives instead, according to LIV: 518, from $* \operatorname{seh}_{1}(y)$ - "to release, loose" (cf. also Lat. sinō "to let, permit"), from which "to send" $\rightarrow$ "throw, hurl, shoot" as in Hitt. $\check{s} a i$-/ši- "to (im)press, to seal".

${ }^{6} \mathrm{IE} * s e w h_{1}$ and $*_{\text {syewh }} h_{l^{-}}$are considered variants of the same root, even if no satisfactory explanations for the presence or loss of $* y$ have been proposed. Anatolian preserved only continuants of $*^{*} \operatorname{sewh}_{1^{-}}$. See Rieken (1999: 479).
} 


\section{Hittite Outcomes of some IE Roots Indicating the Act of Weaving}

The Hittite terms connected in different ways with the idea of "weaving" as well as the IE roots to which they can be traced back, are given below. The different formal outcomes and meanings in the various IE languages are also shown. Hittite lexemes that cannot be traced back to an IE root indicating, if not the act of "weaving", at least the idea of "connecting together" (even if their historical semantics can be considered associable with the act of weaving) will not be listed.

The roots which are involved in this reasoning and which will be analyzed - in the light of Hittite historical developments - are:

- *webh- "to weave, to tie", but also "to move quickly" (IEW: 1114, LIV: $658)$.

- *tek̂k(s)- "to weave, connect, hew", but also "to fabricate, especially with an ax", "to make wicker or wattle fabric for (mud-covered) house walls" (IEW: 1058, LIV: 619).

- ${ }^{*} \operatorname{seh}_{1^{-}}$"to impress, insert, connect $\rightarrow$ to sew" (IEW: 889-890, LIV: 517).

- *s(y)ewh $h_{1^{-}}$"to sew" (IEW: 915-6, LIV: 545), even if it is not productive and is only attested in one nominal form.

In Hittite, among the verbs which convey a meaning connected with the idea of "weaving", are verbs such as takš- "to devise, to unify, to undertake, to mingle", wep- "to weave" (and derivatives such as, perhaps, wepa- "cloth/fabric"), šai-/ši-; šiya- "to impress, to prick, to seal, press down" and perhaps also šar-, šariya- "to sew (on), embroider" (although its meaning is not fully clear).

Among the verbs that do not immediately convey a meaning connected with the idea of weaving but that express, semantically, the idea of "to assemble, gather, unite", only talupp-/tarupp- is mentioned (see also taluppa"clod of land, of clay", which in Melchert's opinion could be a deverbative noun from the above-mentioned verb) ${ }^{7}$. The semantics of the Hittite verb, according to Melchert (1998), must have originally expressed the idea of connecting together materials that easily self-adhere (also raw wool and spun yarn), and only later was it extended to apply to people or other objects. At the end of this semantic shift (from the more general to the more specific), it assumed the secondary usage of indicating the technique of twisting strands of pliable material together. With regard to the original IE root, Melchert suggests the possibility of tracing back tarupp- to IE *rewp- (IEW: 870, LIV: 510; cf. Lat. rumpō "to break", Old English rēofan id., Old Icelandic reyfi "plucked wool" etc.), which probably must have meant either "to break" or "to pluck,

\footnotetext{
7 "The word [...] is attested chiefly in purification rituals where the cleansing material is pressed against the client's body and absorbs the afflicting sickness or other evil" (Melchert 1998: 47). The scholar stresses that the fact that the word taluppa- is not yet attested referring to wool could be due to an accidental gap: our knowledge of this lexical area is in fact extremely limited.
} 
snatch". The author's conclusion, then, is that "if one snatches with the hand material which naturally self-adheres, such as clay, dough, or raw wool, the immediate result is that one gathers a handful" (Melchert 1998: 50). This is an example of a Hittite word, probably connected with the idea of weaving, that can be traced back to an IE root whose basic meaning was not specifically "to weave, to sew" or similar.

As will be seen, however, a problem arises in the case of a verb which Puhvel (HED 3: 384) cites as huppai-, and which, in his view, means "to interlace, entangle, ensnare, commingle, (make a) blend (of)", (intr.) "mix, mingle" (see, perhaps, also huppa- "blending, mixing", hup (p)ala- "fishnet", $\mathrm{GAD}_{\text {hup }}$ (p)ara-, hupra- "a type of cloth"), contrary to most other scholars, who, as will be illustrated later, have expressed different opinions.

Even if these verbal forms have been generally (even if differently) traced back to the above-mentioned Indo-European roots, they present some problems, in some cases due to their graphic-phonological shape and to the semantic interpretation of the documented forms, which is sometimes quite difficult. In the case of huppai-, in particular, the notion of "weaving" - which could emerge only through the connected semantics of "interlace" (only according to Puhvel's interpretation) - is still obscure, and that is the reason why other scholars (see below) have advanced different opinions about the meaning of the verb. Here follow some of the forms that are pertinent to this overview:

- takš- "to devise, to unify, undertake, mingle" < *tek $(s)$ - "to weave, connect, hew", but also "to fabricate, especially with an ax", "to make wicker or wattle fabric for (mud-covered) house walls" (IEW: 1058, LIV: 619).

As LIV (620, note 1) outlines, the Hittite figurative meaning "to undertake, strive, endeavour" could have spread from the original desiderative meaning "to desire to weave/plait". Also in the Old Persian form ham-atax̌́ata "he strove, endeavoured" the same figurative meaning documented in Hittite emerges, if we consider it a development of the same $\operatorname{root}^{8}$. The noticeable vowel $a$ in the Hittite form taks is due to the development $* e>a$ before a consonant cluster.

It is difficult to determine the exact meaning of the verb, given the wide semantic spectrum that characterizes it. All the roots that have been proposed as archetypes of the Hittite forms present a voiceless final stop, which seems to correspond to the attested forms, documented with the double spelling in an intervocalic position (tág-ga-aš[-mi], ták-ki-iz-zi etc.).

A possible Lydian cognate could be taśo- "to order" (LW: 211), even if the semantic connection does not seem completely evident. Because of the wide range of meanings documented in Hittite the basic sense of the verb is not clearly definable and various etymological connections with different IE roots are possible.

\footnotetext{
${ }^{8}$ For alternative etymological proposals see LIV (620 note 3).
} 
A first possibility is an origin from IE *tek-s (IEW: 1058) / *tek-s (LIV: 619) "to weave, to connect" (Sturtevant 1930: 214, Oettinger 1979: 219).

In this case, the cognate forms would be Skr. taks- "to hammer, form,

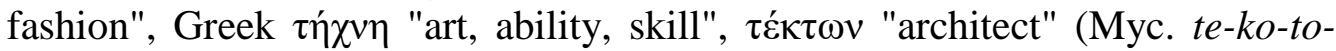
$n^{\circ}$ !), Lat. texō "to weave, put together, construct", tēla "linen, web" <*teks-lā, Skr. takșan- "carpenter", OAv. tāšt "to fashion", MHG dehsen "to break/swing flax", OHG dehsala "axe", etc.

Another proposal (Pedersen 1938: 139-144) could be the reconstruction of the root *dha-k- "to do, to build" (with a $k$-enlargement from *dhe- "to put, to

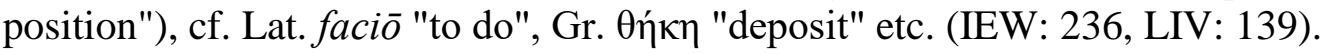

In this case, in particular, a strong formal comparison could be recognized between Hitt. takšs- and Lat. (intensive) facessō "to do intensely".

Laroche $(1963: 69,71)$, instead, has traced back the form to IE $* d e \hat{k}$ - "to take, to perceive, to consider" (IEW: 189-190, LIV: 109), so that Gr. $\delta \varepsilon ́ \kappa o \mu \alpha 1$ "to accept, to receive, to consider", Skr. daśasyáti "respects", Lat. decet "befits" etc. can be compared.

- ร̌ar-, šariya- "to sew (on), embroider (?)" < *ser- "to string together, connect" (IEW: 911, LIV: 534).

As for šar-, šariya- "to sew (on), embroider (?)", the interpretation of the meaning of the verb is not fully clear. It should be connected with the noun šariya- "line, file". CHD (Š: 259), followed by Kloehhorst (2008: 727), hypothesizes a derivation from the same root from which Lat. serō "to link, join", Gr. Elp $\omega$ "to string/knit together", OLith. seris "thread", OIc. sørvi "collar" etc. derive, i.e. IE *ser-. Furthermore, the meaning of the verb seems to be nearer to the idea of "embroidering" rather than of "weaving", since it is often attested in contexts where gold or other precious objects or stones occur (CHD: Š: 259). Only in passages referring to meat could it mean "to truss, to sew together", after the flesh has been butchered and salted.

- wep- "to weave" (?)<*webh- "to weave, to tie", but also "to move quickly" (IEW: 1114, LIV: 658). Derivatives: wepa- "cloth/fabric" (?). Cf. Skr. ubhnấti "tightens, ties, forces", Myc. e-we-pe-se-so-me-na "which will be

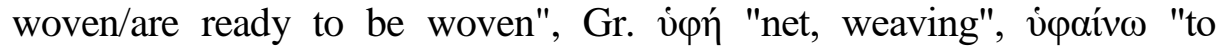
weave" (DELG: 1163-4), OHG weban, TochA wäp, TochB wāp-id. etc.

The verb and its derivatives constitute a figura etymologica (ú-e-pu-uš [acc. plur.] ú-e-ep-ta) which Neu (1998: 59) translates as "(he) wove fabrics" and traces it back to IE *webh- "to weave", supported by the mentioning - in the following sentence - of TÚG "clothing", even though this value is only deducted from the context. The single spelling of the internal labial stop points regularly - according to Sturtevant's Law (i.e. single and double spelling of stops representing, respectively, inherited voiced/voiced aspirated and voiceless stops $)^{9}-$ to an original voiced consonant.

\footnotetext{
${ }^{9}$ For this topic see two recent studies by Pozza $(2011,2012)$.
} 


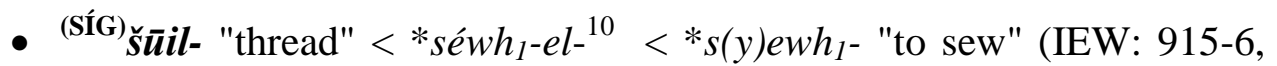

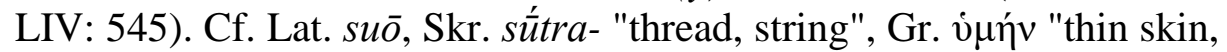
sinew", etc.

As outlined by Kloekhorst (2008: 777), the root *syewh ${1^{-}}^{-}$"to sew" is continued, in Hittite, only in this noun, so there is no productive verb which preserved traces of the original root.

- hu(wa)pp-, huppai-, huppiya- "interlace, entangle, ensnare, commingle, (make a) blend (of)", (intr.) "mix, mingle" - in the opinion of HED (3: 384) / "to cast, hurl down" (huwapp- + accusative), "to do evil against" (huwapp- + dative-locative), "to heap together, make a heap" (huppai-), "to play the huhupal-instrument" (huppiya-) - in Melchert's opinion (2007).

The first problem connected with this verb is represented by the fact that only Puhvel (HED 3: 384) interprets it semantically as "interlace, entangle" and differentiates it from the lemma huwapp-, which he translates as "ill-treat, harrow, harass, disfigure, spoil" (HED 3: 430).

Only within the semantic framework outlined by Puhvel, then, can huppaibe considered a form associated with the semantic idea of "weaving", and this is the only reason why the main interpretations concerning the form in question will be summarized.

If we connect this verb with Skr. ubhnáti "tightens, ties, forces", Myc. $e$ we-pe-se-so-me-na "which will be woven/are ready to be woven" (Hajnal 2002), Gr. vi TochB wapp-id. etc., we have to hypothesize an origin from *webh- "to weave" (IEW: 1114; LIV: 658; HED 3: 386; HEG A-K: 290).

Kloekhorst (2008: 431), alternatively, compares it with Goth. ubils "evil" (following Juret 1942), OHG ubil id., Skr. vap- "to strew (out), to scatter (seed)" etc., and reconstructs an IE root of the type $* h_{2} w e p h_{1^{-}}$"to hurl, to throw" (IEW: 1149, LIV: 684). The root-final laryngeal $* h_{1}$ is postulated by the scholar in order not to contradict his hypothesis of lenition of an original voiceless stop after $*_{o} \delta^{11}$ : the laryngeal would prevent the lenitional process, causing, as a consequence, the secondary gemination of the labial stop. In any case, determining the meaning of the Hittite verb is problematic.

In light of the first reconstruction (IE*webh-) the only assumption that can explain an initial $h$ in Hittite is the one that reconstructs an IE root beginning with $* H$. According to Beekes (1969), in particular, the Mycenaean future

\footnotetext{
${ }^{10} \mathrm{IE} *$ sewh $_{l^{-}}$and $*$ syewh $h_{l^{-}}$are to be considered variants of the same root (see footnote 6 ).

${ }^{11}$ Kloekhorst (2008: 65, 98, passim) assumes a lenition after $* o ́(>\mathrm{PA} . * / \overline{0} />$ Hitt. $/ \bar{a}-/)$ in order to explain the frequent cases of paradigmatic alternation in hi-verbs between a single consonant in the III sing. pres. act. and a double one in the III plur. pres. act. (see ištâpi: ištappanzi). The scholar then extends its action with the aim to explain other irregular cases such as $a k(k)$-, ek- "to die, to be killed" <* $h_{1 / 3}$ ók-ey / *h $h_{1 / 3} k$-énti (aki / akkanzi), -ātar / -ānn("abstract" suffix) < *ótr / *ótn-, ištāp- / ištapp- "to (en)close, shut, block" < *stóp-ey / *stpénti (ištāpi / ištappanzi), šākuwa- "eyes" < *sók $k^{w}-o$ - < $*_{s-h_{3}} e k^{w}$ - "to see" etc.
} 


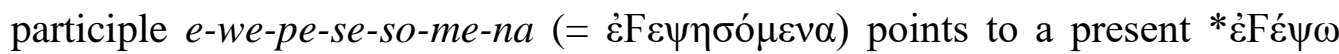
from an IE root with an initial laryngeal, i.e. ${ }^{*} h_{l} w e b h-$ : the Mycenaean form would show, through a prothetic /e/, its regular outcome. More precisely, this would be a case of the so-called "false prosthesis" (Austin 1941), that is to say that we are dealing, instead, with an inherited part of the original root. Pure prosthesis - which implies that a vocalic element is added initially to the root for mere phonetic reasons - is in fact rarer.

The double spelling of the internal labial, in Hittite, however, is striking with regard to Sturtevant's Law. In particular, according to LIV: 658, huppai-, huppiya- cannot be ascribed to the IE root*webh-precisely because of the geminate spelling of the labial stop and of the presence of an initial $h$-.

Hajnal (2002: 206-207) suggests solving this problem by assuming that the consistent double writing of $-p p$ - is the result of an assimilation of the type $*_{-}$ $m b(h)->-p p-\left(\right.$ phonetic $\left./{ }^{\circ} \mathrm{bb}^{\circ} /\right)$, exactly as in the case of Hitt. ištāp- / ištapp"to block, to enclose, to shut", from a previous *ste $(m) b h$ - (Benveniste 1932: 139; Melchert 1994: 270). So, forms like hu-u-up-pa-an-zi /húbbant i/ come from an original nasal-infixed present /humbanti/ <*/Humbh-énti/.

Notwithstanding the double spelling of the medial stop, Puhvel (HED 3: 386) considers plausible, for huppai-, the reconstruction of an IE root characterized either by an enlargement in a labial voiced aspirated stop (of the type $\left.* A_{l} u b h-\right)^{12}$ or ending in voiceless stop (of the type $* A_{l} u p-$ ). He considers hupp- and huwapp- two different lexemes, the first indicating "to interlace, entangle, ensnare, commingle, (make a) blend (of)", (intr.) "mix, mingle", and the second "to spoil, disfigure, harass". In his view (HED 3: 432), hupp-could represent a semantic offshoot of the same root, as in the Engl. warp in the figurative sense of "distort, disfigure" ${ }^{13}$.

The majority of other scholars, on the other hand (see in particular HEG A-K: 290 and Kloekhorst 2008: 369 ff.), consider hupp- a graphic variant of huwapp-, the same representing phonologically /hwap \% In their opinion, huwapp-and hupp- are originally identical (the meaning "to be hostile towards, to do evil against" can be derived from a previous meaning "to hurl, to throw down").

A brilliant explanation of this problematic issue has been recently offered by Melchert (2007), who, through careful philological investigations, has reached the conclusion that the verbs erroneously linked by Puhvel should actually be distinguished. In Hittite, therefore, four different verbs are documented: huppiya- "to play the huhupal-instrument", huwapp- "to do evil against", huwapp- "to cast, hurl (down)", and huppa(i)- "to heap (together), make a hip".

In Melchert's view, in particular, there is no compelling evidence for any of the assigned meanings listed by Puhvel.

\footnotetext{
${ }^{12}$ With $* A_{l}$ Puhvel intends a voiceless $a$-coloring laryngeal, preserved in Hittite.

13 For a metaphorical use of the expression šākuwa katta hu(wa)pp- "to throw down as to the eyes, face down" (lit. "mit den Augen nach unten gewendet beschädigen") see Oettinger (1976: 44) and for a comparison with Skr. vápati "to throw, strew", Ved. ní-vapati "throw down, shatter", see Melchert (1988: 233).
} 
Szemerényi (1974: 154) compares the deverbal neuter abstract *hu(wa)ppar "maltreatment, outrage", which unfortunately is documented in a fragmentary context (KUB 34.73, 7 apaš idalawanni hu-wa-a[p...), with Gr. v̋pis "insolence, outrage" (see also the adjective huwappa- "bad"), considering the Greek form a borrowing from Hittite. In particular, the scholar (Szemerényi (1974: 154) observes that "since the Western part of Asia Minor was in all likelihood populated by Luwian speakers, it is of interest to note the Luwian tendency to generalise $i$-stems".

\section{Conclusion}

As illustrated in this brief contribution, not all the principal IE roots indicating the act of weaving are fully documented in Hittite. In particular, after the new semantic intepretations of huwapp- and huppai- advanced by Melchert (2007), the semantic counterpart of IE *webh- seems to be preserved in Hittite only in the verb wep-, provided that its meaning is really to be interpreted as "to weave": in fact there is only indirect (i.e. contextual) evidence that its meaning was really connected with the idea of "weaving".

In regards to *hu(wa)pp-, on the other hand, neither the semantics nor the formal structure (especially due to the presence of the initial $h$ in Hittite) allow us to consider it a direct outcome of *webh-, especially since Hittite wep- is formally more regular compared to the original root.

\section{Acknowledgments}

This paper is the result of a study sponsored and financed in 2014 by Sapienza University of Rome ("La terminologia tessile nel Mediterraneo orientale e Vicino Oriente antico tra II e I millennio a.C. Lingue, culture e contatti").

\section{References}

Austin WM (1941) The Prothetic Vowel in Greek. Language 172: 83-92.

Baccelli G, Bellucci B, Vigo M (eds.) (2014) Elements for a Comparative Study of Textile Production and Use in Hittite Anatolia and in Neighbouring Areas. In M Harlow, C Michel, M-L Nosch (eds.), Prehistoric, Ancient Near Eastern and Aegean Textiles and Dress. An Interdisciplinary Anthology (pp. 97-142). Oxford, Philadelphia: Oxbow.

Bachvarova MR (2016) From Hittite to Homer. The Anatolian Background of Ancient Greek Epic. Cambridge: Cambridge University Press.

Beekes RSP (1969) The Development of the Proto-Indo-European Laryngeals in Greek. Den Haag, Paris: Mouton.

Benveniste É (1932) Sur le consonantisme hittite (On Hittite consonantism). Bulletin de la Société de Linguistique de Paris 33: 136-143. 
CHD = Güterbock HG, Hoffner HA Jr., van den Hout ThPJ (eds.) (1980) The Hittite Dictionary of the Oriental Institute of the University of Chicago. Chicago: The Oriental Institute of the University of Chicago.

Čop B (1963) Zu einigen Bildungen mit Labialformans im Hethitischen (Hittite Formations with Labial Extension). In R von Kienle, A Moortgat, H Otten, E von Schuler, W Zaumseil (eds.), Festschrift Johannes Friedrich zum 65. Geburtstag am 27. August 1958 gewidmet (Festschrift Johannes Friedrich on the Occasion of His 65th Birthday on 27 August 1958). Heidelberg: Winter: 91-103.

Dardano P (2010) La veste della sera: echi di fraseologia indoeuropea in un rituale ittito-luvio (The Dress of the Evening: Echoes of Indo-European Phraseology in a Hittite-Luwian Ritual). In MG Biga, M Liverani (eds.), Ana turri gimilli. Studi dedicati al Padre Werner R. Mayer, S.J. da amici e allievi (Ana turri gimilli. Studies dedicated to Father Werner R. Mayer S.J. from Friends and Students). Vicino Oriente 5: 75-84.

DELG = Chantraine P (1968-1980) Dictionnaire étimologique de la langue grecque (Etymological Dictionary of the Greek Language). Paris: Klincksieck.

Frangipane M, Andersson Strand E, Laurito R, Möller-Wiering S, Nosch, M-L, RastEicher, A, Wisti Lassen, A (eds.) (2009) Arslantepe (Turkey): Textiles, Tools and Imprints of Fabrics from the $4^{\text {th }}$ to the $2^{\text {nd }}$ Millennium BC. Paléorient 35(1): 5-30.

Goetze A (1947) The Priestly Dress of the Hittite King. Journal of Cuneiform Studies 1: 176-185.

Goetze A (1955) Hittite Dress. In H Krahe (eds.), Corolla Linguistica. Festschrift Ferdinand Sommer zum 80. Geburtstag am 4. Mai 1955 (Corolla Linguistica. Festschrift Ferdinand Sommer on the Occasion of His 80th birthday on the 4th May 1955) (pp. 48-62). Wiesbaden: Harrassowitz.

Goetze A (1956) The Inventory IBoT I 31. Journal of Cuneiform Studies 10: 32-38.

Gusmani R (1968) Il lessico ittito (Hittite Lexicon). Napoli: Libreria Scientifica.

Hajnal I (2002) Mykenisch $e$-we-pe-se-so-me-na und die Frage eines frühgriechischen Umlauts (Mycenaean e-we-pe-se-so-me-na and the Question of an Early Greek Umlaut). In M Fritz, S Zeilfelder (eds.), Indogermanica. Festschrift fur Günter Neumann zum 80. Geburtstag (Indogermanica. Festschrift for Günter Neumann on the Occasion of his 80th birthday) (pp. 201-213). Graz: Leykam.

HED = Puhvel J (1984) Hittite Etymological Dictionary. Berlin, New York: Mouton de Gruyter.

HEG = Tischler J (1983) Hethitisches Etymologisches Glossar; mit Beiträgen von Günter Neumann (Hittite Etymological Glossary; With Contributions by Günter Neumann). Innsbruck: Institut für Sprachwissenschaft der Universität Innsbruck.

Hoffner HA Jr., Melchert HC (2008) A Grammar of the Hittite Language. I. Reference Grammar. Indiana, Winona Lake: Eisenbrauns.

Hrozný B (1915) Die Lösung des hethitischen Problems (The Solution of the Hittite Problem). Mitteilungen des Deutschen Orientgesellschaft 56: 17-50.

IEW = Pokorny J (1994) (3rd edn.). Indogermanisches etymologisches Wörterbuch (Indo-European Etymological Dictionary). Tübingen, Basel: Francke.

Juret A (1942) Vocabulaire étymologique de la langue hittite (Etymological Vocabulary of the Hittite Language). Limoges: Bontemps.

Klengel H (2008) Studien zur hethitischen Wirtschaft 4. Das Handwerk. Werkstoffe: Wolle und Leder, Holz und Rohr (Studies on the Hittite Economy 4. The Craft. Materials: Wool and Leather, Wood and Pipe). Altorientalische Forschungen 35(1): 68-85.

Kloekhorst A (2008) Etymological Dictionary of the Hittite Inherited Lexicon. Leiden, Boston, Köln: Brill. 
Laroche E (1963) Études lexicales et étymologiques sur le hittite (Hittite Lexical and Etymological Studies). Bulletin de la Société de Linguistique de Paris 58: 58-79.

Laroche E (1971) Catalogue des Textes Hittites (Catalogue of Hittite Texts). Paris: Klincksieck.

Laurito R (2013) Textile Production: Some Notes on Spinning and Weaving Tools. In F Manuelli (eds.), Arslantepe - The Late Bronze Age Assemblages. Hittite Influence and Local Traditions in an Eastern Anatolian Community (pp. 224233). Roma: Sapienza Università di Roma, Dipartimento di Scienze dell'Antichità.

Lazzeroni R (1967) Su alcuni aspetti della lingua di Omero (On Certain Aspects of the Language of Homer). Studi e Saggi Linguistici 7: 49-62.

LIV = Rix H, Kümmel, M (eds.) (2001) Lexikon der indogermanischen Verben. Die Wurzeln und ihre Primärstammbildungen. Zweite, erweiterte und verbesserte Auflage bearbeitet von Martin Kümmel und Helmut Rix (Lexicon of Indo-European verbs. The Roots and Their Primary Stem Formations. Second, Extended and Improved Edition by Martin Kümmel and Helmut Rix). Wiesbaden: Reichert.

Melchert HC (1988) Luvian Lexical Notes. Historische Sprachforschung 101: 211-243.

Melchert HC (1994) Anatolian Historical Phonology. Amsterdam, Atlanta: Rodopi.

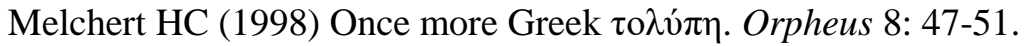

Melchert HC (2007) Hittite huwapp-, huppā(i)- and huppiya-. In D Groddeck, M Zorman (eds.), Tabularia Hethaeorum. Hethitologische Beiträge Silvin Košak zum 65. Geburtstag (Tabularia Hethaeorum. Hittitological Contributions Offered to Silvin Košak On Her 65th birthday) (pp. 513-519). Wiesbaden: Harrassowitz.

Michel C, Nosch M-L (2010) Textile Terminologies. In C Michel, ML Nosch (eds.), Textile Terminologies in the Ancient Near East and Mediterranean from the Third to the First Millennia BC (pp. vii-xviii). Oxford: Oxbow.

Neu E (1998) Hethitisch ši-mu-uš (Hittite ši-mu-uš). Historische Sprachforschung 111: 55-60.

Oettinger N (1976) Die militärische Eide der Hethiter (The Military Oath of the Hittites). Wiesbaden: Harrassowitz.

Oettinger N (1979) Die Stammbildung des hethitischen Verbums (The Formation of the Hittite Verb). Nürberg: Carl.

Pedersen H (1938) Hittitisch und die anderen indoeuropäischen Sprachen (Hittite and the Other Indo-European Languages). København: Levin \& Munksgaard.

Pozza M (2011) La grafia delle occlusive intervocaliche in ittito. Verso una riformulazione della lex Sturtevant (The Spelling of Intervocalic Stops in Hittite. Towards a Reformulation of Sturtevant's Law). Roma: Il Calamo.

Pozza M (2012) Reflections on Some Problematic Cases for Sturtevant's Law. Indogermanische Forschungen 117: 257-282.

Rieken E (1999) Untersuchungen zur nominalen Stammbildung des Hethitischen (Investigations on Hittite Nominal Formation). Wiesbaden: Harrassowitz.

Sturtevant EH (1930) The Gutturals in Hittite and Indo-European. Language 6: 213-228.

Szemerényi O (1974) The Origins of the Greek Lexicon: Ex Oriente Lux. The Journal of Hellenic Studies 94: 144-157.

van den Hout Th.PJ (2011) The Elements of Hittite. Cambridge: Cambridge University Press.

Vigo M (2010) Linen in Hittite Inventory Texts. In. C Michel, ML Nosch (eds.), Textile Terminologies in the Ancient Near East and Mediterranean from the Third to the First Millennia BC. Oxford: Oxbow.

Vigo M (forthcoming) Vestimenta Hethaeorum: Hittite Textile Lexicon (Texte der Hethiter Band 30). Heidelberg: Winter.

Watkins C (1969) A Latin-Hittite Etymology. Language 45: 235-242. 
